\title{
Assignment of the tumor protein p53 induced nuclear protein 2 (TP53INP2) gene to human chromosome band 20q11.2 by in situ hybridization
}

\author{
J. Nowak, ${ }^{a}$ D. Depetris, ${ }^{\text {b }}$ J.-L. lovanna, ${ }^{a}$ M.-G. Mattei ${ }^{b}$ and M.-J. Pébusque ${ }^{a}$ \\ a INSERM U624, Marseille; ${ }^{~}$ INSERM U491, Marseille (France)
}

Manuscript received 28 May 2004; accepted in original form for publication by H.P. Klinger 11 June 2004.

\section{Rationale and significance}

The human TP53INP2 gene was identified by using bioinformatic analyses which include the cDNA sequence named C20ORF110 (Strausberg et al., 2002). It is composed of five exons spanning $9 \mathrm{~kb}$ of genomic DNA. The predicted open reading frame of TP53INP 2 cDNA codes for 220 amino acids with a predicted molecular weight of $24 \mathrm{kDa}$.

TP53INP2 shows a conserved exon-intron structure with the TP53INP1 $\beta$ isoform, a gene strongly activated during cellular stress by $\mathrm{p} 53$-mediated activation of transcription (Tomasini et al., 2002, 2003) that has been assigned to human chromosome 8q22 (Nowak et al., 2002). Protein sequence comparison showed 30 and $45 \%$ of identity and similarity between the two genes, respectively. We report here that TP53INP2 is located at human chromosome 20q11.2.

\section{Materials and methods}

Identification of a human PAC specific to TP53INP2

Comparison of the human TP53INP1 cDNA sequence (access number: NM_033285, Tomasini et al., 2002) with GenBank entries using blastx (http://www.ncbi.nlm.nih.gov/BLAST/) led to the identification of TP53INP2 as part of Homo sapiens chromosome 20 genomic contig (access number: NT_028392), and was annotated as chromosome 20 open reading frame 110 gene (C20orf110, NM_021202). A back-validation BLAST step confirmed sequence homology with TP53INP1. The name of tumor protein p53 inducible nuclear protein 2 (TP53INP2) was approved by the HUGO Gene Nomenclature for C20ORF110.

Supported by INSERM and grants from the Association pour la Recherche contre le Cancer. JN is a recipient of a fellowship from INSERM and Conseil Régional PACA.

Corresponding author: Dr. Marie-Josèphe Pébusque, INSERM U624, Cell Stress Parc Scientifique et Technologique de Luminy

Case 915, F-13288 Marseille Cedex 9 (France)

telephone: +33-491-827543; fax: +33-491-826083

e-mail: pebusque@marseille.inserm.fr

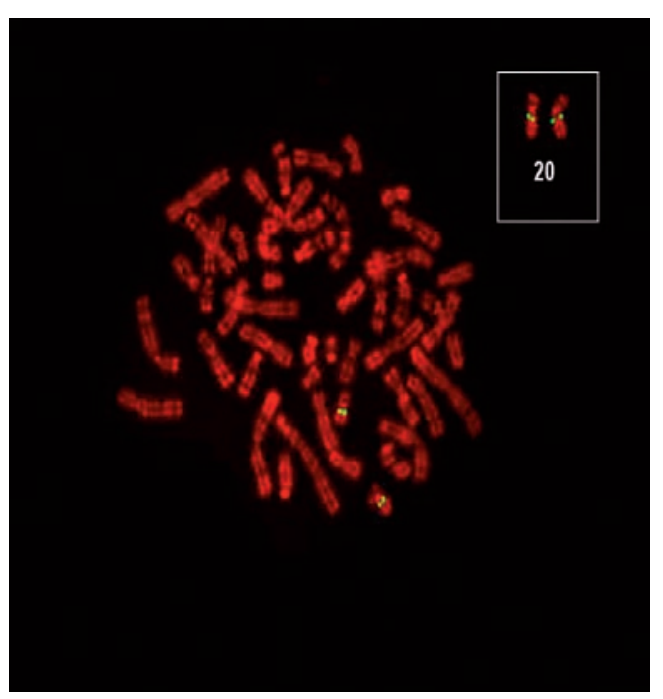

Fig. 1. FISH mapping of the TP53INP2 probe to human metaphase: The green fluorescent signals correspond to the FITC-TP53INP2 probe, located at the 20q11.2 band. Chromosomes are counterstained in red with propidium iodide.

Human male genome P1 artificial chromosome library (PAC N704) from Resource Center of the German Human Genome Project (RZPD) was then screened in silico using the TP53INP2 cDNA sequence and PAC RPCIP704N031181Q was identified.

Fluorescence in situ hybridization on the human genome

Metaphase spreads were prepared from phytohemagglutinin-stimulated human lymphocytes, cultured at $37^{\circ} \mathrm{C}$ for $72 \mathrm{~h}$. 5-bromodeoxyuridine $(60 \mu \mathrm{g} / \mathrm{ml})$ was added for the final $7 \mathrm{hr}$ of culture to ensure a chromosomal R-banding of good quality.

The TP53INP2 PAC clone was labeled by random priming with biotin 14-dCTP (Bioprime DNA labeling system, Invitrogen). Hybridization to chromosome spreads was done using a standard protocol (Pinkel et al., 1986). For each slide, $50 \mathrm{ng}$ of labeled DNA was used. Before hybridization, the probe was annealed with a 150 -fold excess amount of Cot- 1 human DNA (Roche Diagnostics) for $45 \mathrm{~min}$ at $37^{\circ} \mathrm{C}$ to compete with the aspecific repetitive sequences.

\footnotetext{
KARGER Fax +41613061234 E-mail karger@karger.ch www. karger.com

(C) 2005 S. Karger AG, Basel 0301-0171/05/1084-0362\$22.00/0
} 
The hybridized probe was detected by means of fluorescence isothiocyanate-conjugated avidin (Vector laboratories). Chromosomes were counterstained and R-banded with propidium iodide diluted in antifade solution, pH 11.0, as described in Lemieux et al. (1992).

\section{Results}

Probe name: RPCI-5 1181N3 (official name) Bank)

Accession ID: AL109824-EMBL, AL109824-NCBI (Gen-

Probe type: PAC clone

Insert size: $92.196 \mathrm{~kb}$

Vector: pCYPAC2

Proof of authenticity: Bam $\mathrm{HI}$ and XhoI restriction enzyme mapping

Gene reference: GenBank NM_021202

Mapping data:

Most precise location: $20 \mathrm{q} 11.2$

No. of cells examined: 25

Number of cells with specific signal: 1 (0), 2 (0), 3 (5), 4 (20) chromatids per cell

\section{References}

Lemieux N, Dutrillaux B, Viegas-Péquignot E: A simple method for simultaneous Ror G-banding and fluorescence in situ hybridization of small single-copy genes. Cytogenet Cell Genet 59:311-312 (1992).

- Nowak J, Tomasini R, Mattei MG, Azizi Samir LA, Dagorn JC, Dusetti N, Iovanna J-L, Pébusque M-J: Assignment of tumor protein p53 induced nuclear protein 1 (TP53INP1) gene to human chromosome band $8 \mathrm{q} 22$ by in situ hybridization. Cytogenet Genome Res 97:140E (2002).

Pinkel D, Straume T, Gray JW: Cytogenetic analysis using quantitative, high sensitivity, fluorescence hybridization. Proc Natl Acad Sci USA 83:2934-2938 (1986).

Strausberg RL, Feingold EA, Grouse LH et al: Generation and initial analysis of more than 15,000 full-length human and mouse cDNA sequences. Proc Natl Acad Sci USA 99:16899-903 (2002).

Tomasini R, Azizi Samir A, Pébusque M-J, Calvo EL, Totaro S, Dagorn J-C, Dusetti NL, Iovanna J-L: p53-dependent expression of the stress-induced protein (SIP). Eur J Cell Biol 81:294-301 (2002).

Tomasini R, Samir AA, Carrier A, Isnardon D, Cecchinelli B, Soddu S, Malissen B, Dagorn JC, Iovanna JL, Dusetti NJ: TP53INP1s and homeodomain-interacting protein kinase-2 (HIPK2) are partners in regulating p53 activity. J Biol Chem 278:37722-37729 (2003). 